TI 2008-012/3

Tinbergen Institute Discussion Paper

Sustainable Nations:

What Do Aggregate Indicators Tell Us?

\author{
J. Ram Pillarisetti \\ Jeroen C.J.M. van den Bergh²
}

' University of Brunei Darussalam;

${ }^{2}$ Autonomous University of Barcelona, Spain, ICREA, Free University, Amsterdam, and Tinbergen Institute. 


\section{Tinbergen Institute}

The Tinbergen Institute is the institute for economic research of the Erasmus Universiteit Rotterdam, Universiteit van Amsterdam, and Vrije Universiteit Amsterdam.

Tinbergen Institute Amsterdam

Roetersstraat 31

1018 WB Amsterdam

The Netherlands

Tel.: $\quad+31(0) 205513500$

Fax: $\quad+31(0) 205513555$

Tinbergen Institute Rotterdam

Burg. Oudlaan 50

3062 PA Rotterdam

The Netherlands

Tel.: $\quad+31(0) 104088900$

Fax: $\quad+31(0) 104089031$

Most TI discussion papers can be downloaded at http:/ /www.tinbergen.nl. 


\title{
Sustainable Nations: What Do Aggregate Indicators Tell Us?
}

\author{
J. Ram Pillarisetti* \\ Faculty of Business, Economics and Policy Studies \\ University of Brunei Darussalam \\ Brunei Darussalam \\ rammp@fbeps.ubd.edu.bn
}

and

Jeroen C.J.M. van den Bergh

Institute of Environmental Science and Technology, \& Department of Economics and Economic History

Autonomous University of Barcelona, Spain jeroen.bergh@uab.es

$\&$

ICREA, Barcelona, Spain

$\&$

Faculty of Economics and Business Administration, \& Institute for Environmental Studies

Free University, Amsterdam, The Netherlands

December 2007

*Correspondence to Dr. J. Ram Pillarisetti, Faculty of Business, Economics and Policy Studies, University of Brunei Darussalam, BE1410 Brunei Darussalam. Tel: 673-

2460929, Fax: 673-2463017, Email: rammp@fbeps.ubd.edu.bn; jramm5@hotmail.com. 


\begin{abstract}
What is a 'sustainable nation' and how can we identify and rank 'sustainable nations'? Are nations producing and consuming in a sustainable way? Aggregate indicators have been proposed to answer these questions. This paper quantitatively compares three aggregate indicators of sustainability: the World Bank's 'Genuine Savings' measure, the 'Ecological Footprint' and the 'Environmental Sustainability Index'. It is concluded that rankings of sustainable nations vary significantly among these indicators. Implications of this disagreement for analysis and policy are suggested.
\end{abstract}

JEL Classification Code: O1, Q2, Q28, F0.

Key Words: Adjusted Net Savings, Ecological Debt, Ecological Footprint, Environmental Sustainability Index, Genuine Savings, Sustainability. 


\section{Introduction}

Environmentally sustainable development is a core national and global issue. But what criteria should be used to decide whether a nation is on a sustainable path? Sustainable development according to the Brundtland Commission is development that "meets the needs of the present without compromising the ability of future generations to meet their own needs” (World Commission on Environment and Development, 1987). National accounting measures such as GDP fail to address several critical dimensions, including environmental sustainability of production and consumption (e.g., van den Bergh, 2007). Research progress in environment and development economics has generated a variety of aggregate indicators to evaluate and monitor sustainable development. A critical question is whether these indicators are able to sufficiently capture the multidimensional nature of sustainable development and identify and rank nations accordingly. A related and important question is whether any of these indicators can identify if all nations together are consuming the eco-system resources at a sustainable level. The purpose of this paper is to critically examine what aggregate measures say about the status of nations and of all humanity in terms of sustainability.

The paper is organized as follows. Section 2 explains the various indicators reflecting sustainability. Section 3 undertakes an empirical analysis in identifying and ranking 'sustainable nations'. Section 4 offers policy implications and concluding remarks.

\section{Aggregate sustainability indicators}

Many indicators have attempted to capture the various dimensions of sustainability. They vary in terms of sub-components as well as the way these are combined or aggregated. 
Prominent among these aggregate indexes are: Genuine Savings (GS), the Ecological Footprint (EF), the Environmental Sustainability Index (ESI), the Genuine Progress Indicator (GPI), and the Index of Sustainable Economic Welfare (ISEW). Other wellknown indexes are HANPP (human appropriation of net primary production) proposed by Vitousek et al. (1986) and the Wuppertal Institute concepts MIPS (material input per unit service), TMF (total material flow) and ecological rucksack which sum direct and indirect material use (measured in $\mathrm{kg}$ ) in production, including land removal in mining (Schmidt-Bleek, 1993). All these indicators rely on some type of reduction of multidimensional effects to a single unit, be it money, energy, kilogrammes or land area. This has been criticized as assuming commensurability of values (Martinez-Alier et al., 1998) or as reflecting some specific value theory (e.g., land, energy or weight value theory) (van den Bergh and Verbruggen, 1999).

While the EF is derived mainly from environmental science, GS, ESI, GPI, ISEW combine environmental with selected macroeconomic and social indicators. Though conceptually seem useful (e.g., Lawn, 2003), no comprehensive data are available across many countries on GPI and ISEW. Moreover, GPI is structurally based on EF components. The material indicators MIPS and TMF are too crude, narrow and indirect to capture environmental effects broadly in an accurate way. Moreover, GS has received considerable interest as it was developed at and published by the World Bank, EF has been marketed extensively by World-wide Fund for Nature International (WWF), and ESI has been supported by World Economic Forum. We therefore limit ourselves to a comparison of GS, EF and ESI in this paper. In addition, comprehensive data are available for them for a large number of countries over many years. The nature of these indicators is briefly discussed below. 


\section{(i) Genuine Savings}

The World Bank (1997) proposed the original genuine savings rate. It has been modified in subsequent years (now re-named Adjusted Net Saving) and is currently calculated as:

$$
G S=\frac{G D S-D_{p}+E D U-\sum R_{n, i}-C O_{2} \text { Damage }-P M 10 \text { Damage }}{G N I}
$$

where GS is genuine savings rate, GDS is gross domestic savings, $D_{\mathrm{p}}$ is depreciation of physical capital, EDU is current expenditure on education, $\mathrm{R}_{\mathrm{n}, \mathrm{i}}$ is the rent from depletion of $\mathrm{i}$-th natural capital (energy, mineral and forest depletion are included), $\mathrm{CO}_{2}$ damage is damage from carbon dioxide emissions (currently estimated as US\$20 per ton of carbon times the number of tons of carbon emitted), and GNI is gross national income at market prices. PM10 damage is based on the estimate of particulate matter less than 10 microns in diameter for all cities with a population of 100,000 or more and is measured using willingness-to-pay to avoid mortality due to particulate emissions (World Bank, 2007). GS is based on 'weak sustainability', which assumes perfect substitutability between physical, natural and human capital. A negative GS value implies that welfare is expected to decline in the future. GS has ranked Fiji at the top of the chart with a genuine saving rate of 38.6 followed by Namibia (34.1), China (31.8) and others. USA also is considered to be on a sustainable path with a genuine saving rate of 3.0. Thirty three countries, including several developing countries, are noted to be on an unsustainable development path. The poorest performers are Chad at the bottom with a genuine savings rate of -58.4 , followed by Uzbekistan (-47.9) and Republic of Congo (47.4).

\section{(ii) The Ecological Footprint}

Proponents of 'strong sustainability' argue that natural capital should be considered separately from economic capital, because at critical stages overuse of ecological assets 
can not be compensated for by economic assets. In line with this thought, Ecological footprint analysis looks at whether nations are living within or beyond their biological capacity. The Ecological Footprint is a measure given in global hectares (that is, hectares of biologically productive space with world-average productivity') that 'measures how much land and water area a human population requires to produce the resources it consumes and to absorb its wastes under prevailing technology' (Wackernagel and Rees, 1996). Ecological Balance can be stated as:

$$
E B=\sum_{i} B C-\sum_{i} F P
$$

If total footprint (FP) exceeds total biological capacity $(\mathrm{BC})$, then the nation is running an ecological deficit; if BC exceeds FP, the nation has an ecological reserve (WWF) et al., 2006; Wackernagel and Rees, 1996). Six categories are taken into account; cropland, pasture, forests, fisheries, built space and energy. The footprint varies in proportion to population size, consumption per capita and resource intensity of prevailing technologies. The Living Planet Report 2006 allocates about 1.8 global hectares (gha) per person to ensure sustainable consumption, given the Earth's productive land and sea space as well as available technologies. The ecological balance is highest in case of Gabon (17.8) followed by Bolivia (13.7), New Zealand (9.0) and others. The bottom level performers are UAE (-11.0), Kuwait (-7.0), USA (-4.8) and others (see WWF et al., 2006).

\section{(iii) The Environmental Sustainability Index (ESI)}

The Environmental Sustainability Index (ESI) was developed by the Yale Centre for Environmental Law and Policy (Bisbort, 2003; YCELP et al., 2005). It uses 76 data sets (e.g., natural resource endowments, pollution levels, environmental management efforts etc) integrated into 21 indicators (I), with each indicator given an equal weight (w).

$$
E S I=\sum_{i=1}^{21} w I_{i}
$$


These 21 indicators fall into five broad categories: (i) environmental systems, (ii) reducing environmental stresses, (iii) reducing human vulnerability to environmental stresses, (iv) societal and institutional capacity to respond to environmental challenges and (v) global stewardship. A higher score implies that a country is relatively better positioned to maintain favorable environmental conditions for the future. Finland ranked at the top with a score of 75.1 followed by Norway (73.4), Uruguay (71.8), Sweden (71.7) and others. North Korea is placed at the bottom with an ESI score of 29.2, with Taiwan (32.7), Turkmenistan (33.1) as second and third poorest performers. While a negative value for GS or ecological balance implies unsustainable development, it is difficult to specify a threshold level for the ESI such that any ESI score above it can be considered to identify a sustainable development path. Though theoretically the ESI score can take values between 0 (most unsustainable) and 100 (completely sustainable), the actual estimates vary between 29.2 and 75.1. YCELP et al. have also classified these estimates in 5 quintile ranges of ESI scores (29.2-40.0; 40.5-46.2; 46.6-52.4; 52.5-59.6; and 59.7-75.1). For this paper, we have arbitrarily chosen an ESI score in bottom two quintiles (that is, an ESI score of 46.2 or less) as a reflection of unsustainable development.

\section{Empirical analysis and policy implications}

Here we compare the three indexes. The frequency distributions of these indexes for the various countries are shown in Figure 1a-c. The distributions of these indexes by income classification are given in Figure 2a-c. The results reflect a wide variation and disagreement among the indexes in ranking nations as 'sustainable'. Table 1 gives the Kendall tau-b rank correlation coefficients between the indexes, as well as with PPP GDP per capita $(\mathrm{Y})$ and the HDI. It can be seen that EF is negatively correlated with $\mathrm{Y}$, the HDI, and GS and positively correlated with ESI, while GS and ESI exhibit positive 
correlation with each other and with $\mathrm{Y}$ and the HDI ${ }^{1}$. The negative and positive (but low) correlation coefficients indicate that the various indicators point in very different directions when addressing sustainability. This is disturbing and suggests that there is still little agreement on what constitutes a good aggregate environmental index and on how to rank nations as 'sustainable nations'. The disagreement is not necessarily surprising as the estimation methods are different in approach and can moreover be criticized on methodological grounds based on aggregation, arbitrary choices and weighting (Pillarisetti, 2005; Ebert and Welsch, 2004; van den Bergh and Verbruggen, 1999; Grazi et al., 2007).

We examined how many countries in different income and HDI groups are considered unsustainable by each indicator independently, by a combination of two indicators, and by all three indicators. Tables 2 and 3 provide information on the number of countries on an unsustainable path by income and HDI classifications of countries ${ }^{2}$. The results further emphasize the lack of agreement among the indexes for a large number of countries. While GS and ESI view many HICs and High HD countries on a sustainable path, EF suggests the opposite. Table 4 (a) provides the list of top 20 performers for each of the indexes, and by all three indexes together (that is, the list of countries reflecting positive and high values of GS, EF and a high value of ESI). Table 4 (b) gives the bottom 20 performers for each index. Here it can be seen that 11 countries are considered unsustainable by all 3 indexes (that is, running an ecological deficit, a

\footnotetext{
${ }^{1}$ Data are collected from a variety of sources: GS from the World Bank (2007); EF from the Living Planet Report (WWF et al, 2006); ESI from YCELP (2005); Y and HDI from the Human Development Report 2006 (UNDP, 2006).

${ }^{2}$ Economies are divided among income groups according to gross national income (GNI) per capita, calculated using the World Bank Atlas method. The groups are: low income countries (LICs), \$765 or less; lower middle income countries (LMICs), \$766-3,035; upper middle income countries (UMICs), \$3,0369385; and high income countries (HICs), \$9,386 or more (World Bank, 2005). The Human Development Report 2005 (UNDP, 2005) classifies countries into three clusters: High Human Development (HDI is 0.8 or above), Medium Human Development (HDI is 0.5 to 0.799 ) and Low Human Development (HDI is less than 05).
} 
negative GS value and an ESI score of 42.6 or less) ${ }^{3}$. While EF positively projects developing countries which generally have relatively small ecological footprints and considers many advanced countries as 'unsustainable nations', GS and ESI by and large rank advanced countries favorably and view many poor countries as 'unsustainable nations'. While ESI considers five HICs (Belgium, Korea Republic, Kuwait, Taiwan and UAE) as unsustainable, GS regards none of the HICs as being on an unsustainable path. Overall, 29 countries (12 LICs, 6 LMICs, 5 UMICs and 6 HICs) are viewed as progressing in a sustainable way by all the three indexes. These include all the 20 countries in column 1 of table 4 (a) as well as Benin, Cambodia, Côte d'Ivoire, GuineaBissau, Madagascar, Mali, Nicaragua, Panama and Tanzania. These 29 countries together have 567 million people, thus covering only approximately 9 percent of the world population. Except for Brazil (with a population of 184 million), the remaining countries are small and medium sized countries (population wise) with population sizes between 1.5 million to 45 million.

Taking a brief critical look at the index construction methodology reveals serious limitations of these indexes. GS is based on perfect substitution of all forms of capital which can yield seriously misleading implications and policies. For instance, if Brazil destroys all Amazonian forests and invests the sale proceeds as education expenditure, GS will stay the same or might increase. By extension, if all countries were to destroy all their forests and invest the proceeds as education expenses, this will have no impact as GS stays the same or increases. Thus relying on GS for policy can result in an “irreversible loss of 'critical natural capital'” (Muradian and Martinez-Alier, 2001). Thus combining the different forms of capital and assuming perfect substitution can yield

\footnotetext{
${ }^{3}$ These 11 countries are out of a subset of 119 countries for which values of all three indexes are available. Countries included in the study are those for which at least one of the index values is available (the most recent values of the indexes are used: GS is available for 128 countries, EF for 147 countries and ESI for 146 countries). Thus the number of unsustainable nations by all three indexes can be much higher than 11 , if data on all three indexes are available for more than 119 nations.
} 
trivial and counter intuitive results (Pillarisetti, 2005). A related problem is that for one country it may perhaps work but not for the whole world. ESI seems more comprehensive but is arbitrary in terms of composition as it does not have a sound theoretical base. For instance, an environmentally important indicator 'eco-efficiency' receives the same weight as 'basic human sustenance', 'participation in international collaborative efforts' and other social and economic indicators. Trade off between social and environmental goals implicitly assumes unlimited substitution which lacks a theoretical basis. This makes ESI as much a social indicator as an environmental one. Thus Bhutan, which maintains a pristine environment, is highly eco-efficient and consumes extremely low amounts of global commons (negligible $\mathrm{CO}_{2}$ and other pollutant emissions) but still obtains almost the same ESI score (53.5) as the USA (53.0) which, with only $5 \%$ of the world population, consumes extremely large amounts of global commons by producing nearly a quarter of world $\mathrm{CO}_{2}$ emissions and significant amounts of other pollutants that cause adverse climate change effects (e.g., Gore, 2007, Sachs, 2005; World Resources Institute et al (2000); Centre for Health and the Global Environment, 2005).

Both GS and ESI reflect bias towards advanced economies and seriously fail to adequately account for consumption of global commons and accumulation of ecological debt (Simms, 2005). EF on the other hand, considers depletion of natural resources as the central element of sustainability and states that from a global perspective, humanity's consumption has exceeded the Earth's carrying capacity by 30\%. It argues that, unless lifestyle changes are seriously changed and consumption of global commons brought down to sustainable levels, humanity at a global level will remain consuming at unsustainable levels. However, at the country level the estimates can yield misleading results as profligate countries may still show an ecological surplus thanks to a well endowed resource base (e.g. Australia) while prudent countries may still reflect ecological 
deficit because of a poor resource base (e.g. Moldova). The ecological deficit/surplus indicator reflects a close to autarkical normative perspective: each country should stay within its ecological capacity defined by its political boundaries. But the latter are arbitrary from an environmental angle, and deny the reasons of international trade and concentration of activities in space (agglomeration effects). The case of China is strange and disturbing as GS ranks China at the top $3^{\text {rd }}$ of the list. But EF considers China as one of the few developing countries running ecological deficit and ESI places China as one of the poor performers. Similarly, Bolivia which is ranked as a top performer $\left(2^{\text {nd }}\right.$ by EF and $19^{\text {th }}$ by ESI $)$ is registered as a bottom performer by GS (10 $10^{\text {th }}$ from the bottom). The largest economy in the world, the USA, is identified as a sustainable nation by GS and ESI, while EF places USA as one of the three worst performers.

The questions of sustainability of humanity's consumption and identifying sustainable nations can not be conclusively answered using the three considered indicators. All indicators reflect methodological and measurement problems, and using each of them to rank sustainable nations or commenting on humanity's consumption may yield erroneous results. Despite the limitations and lack of agreement among the various indicators, it might be worthwhile to check which nations are ranked low according to all indexes, according to EF and ESI, or EF and GS or ESI and GS. Besides the above 11 nations identified as the bottom performers by all indexes, EF and ESI also jointly identify 42 nations as unsustainable; EF and GS jointly consider 14 countries as unsustainable; and ESI and GS jointly view 17 countries as unsustainable. These nations perhaps most urgently would need to critically examine their economic development and environment policies. 


\section{Concluding remarks}

Three aggregate indexes to analyze humanity's consumption yield conflicting results. All indexes suffer from methodological limitations: GS can yield erroneous and counterintuitive results: by assuming infinite substitution across all forms of capital, it under weighs the loss of critical natural capital. GS and EDI seem to reflect a GDP bias. While GS considers all high income countries as sustainable, ESI views all but 5 high income countries as sustainable. Neither GS nor ESI can answer whether humanity's consumption is sustainable and within the limits of the eco-system capacity. EF on the surface seems to suggest that humanity's consumption is overshooting and beyond the Earth's regenerating capacity, but the methodological problems associated with EF can make the estimate unreliable. In particular, the notion that the footprints should remain within ecological capacity as defined by arbitrary national borders reflects an anti-trade bias. A disturbing fact is that only a fraction of 29 countries in the world economy are viewed as sustainable by all three indexes jointly. This may be taken as a suggestion at least that the majority of the nations in the world need to reexamine the environmentdevelopment linkages and policies. Moreover, for many small and other vulnerable nations, the GS and ESI indexes do not capture the vulnerability of nations to humaninduced climate change, whereas the EF does this in a very arbitrary and thus inaccurate way (namely through forestation to capture or compensate for $\mathrm{CO}_{2}$ emissions). A comprehensive approach taking more realistically account of the consumption of global commons, ecological impact and environmental ethics is needed to track progress towards sustainable development. 


\section{References}

Bisbort, A. (2003). The Environmental Sustainability Index: A new paradigm for global decision making. Environment: Yale - The Journal of the School of Forestry and Environmental Studies, 2(1), 3-11.

Centre for Health and the Global Environment. (2005). Climate change futures: health, ecological and economic dimensions. (Boston: Harvard Medical School).

Ebert, U. \& Welsch, H. (2004). Meaningful environmental indices: a social choice approach. Journal of Environmental Economics and Management, 47, 270-283.

Gore, A. (2007). An inconvenient truth: the crisis of global warming. (New York: Viking).

Grazi, F., van den Bergh, J.C.J.M. \& Rietveld, P. (2007). Welfare economics versus ecological footprint: modeling agglomeration, externalities and trade. Environmental and Resource Economics, 38(1): 135-153.

Lawn, P.A. (2003). A theoretical foundation to support the Index of Sustainable Economic Welfare (ISEW), Genuine Progress Indicator (GPI), and other related indexes, Ecological Economics, 44(1): 105-118.

Martinez-Alier, J., Munda, G. \& O’Neill, J. (1998). Weak comparability of values as a foundation for ecological economics. Ecological Economics, 26, 277-86.

Muradian, R. \& Martinez-Alier, J. (2001). Trade and the environment: from a 'Southern' perspective. Ecological Economics, 36, 281-297.

Pillarisetti, J. R. (2005). The World Bank's 'genuine savings' measure and sustainability, Ecological Economics, 55, 599-609.

Sachs, J. (2005). Climate change and war. (New York: Global Policy Forum).

Schmidt-Bleek, F. (1993). MIPS - a universal ecological measure? Fresenius Environmental Bulletin, 2 (8), pp. 306-311. 
Simms, A. (2005). Ecological debt: the health of the planet and the wealth of nations. (Ann Arbor: University of Michigan Press)

United Nations Development Programme (2000-2006). The Human Development Reports (New York: Oxford University Press).

van den Bergh J.C.J.M. (2007). Abolishing GDP. Tinbergen Institute Discussion Paper 07-019/3. (Amsterdam and Rotterdam: Tinbergen Institute).

van den Bergh J.C.J.M \& Verbruggen, H. (1999). Spatial sustainability, trade and indicators: an evaluation of the Ecological Footprint. Ecological Economics, 29, 61-72. Vitousek, P.M., Ehrlich, P.R., Ehrlich, A.H. \& Matson, P.A. (1986). Human appropriation of the products of photosynthesis. BioScience, 36, pp. 368-373.

Wackernagel, M. \& Rees, W. (1996). Our ecological footprint: reducing human impact on the earth. (Gabriola Island, Canada: New Society Publishers).

World Bank. (1997). Expanding the measure of wealth. (Washington, DC: World Bank). World Bank. (2005-2007). World development Indicators. (Washington, DC: World Bank). World Commission on Environment and Development (1987). Our common future. (New York: Oxford University Press).

WWF, Zoological Society of London \& Global Footprint Network. (2006). Living planet report 2006. (Gland, Switzerland: WWF).

World Resources Institute, United Nations Environment Programme, United Nations Development Programme, \& World Bank. (2000). World resources 2000-2001, people and ecosystems: the fraying web of life. (Washington, DC: World Resources Institute).

Yale Centre for Environmental Law and Policy, Center for International Earth Science Information Network (CIESIN), \& the World Economic Forum. (2005). Environmental Sustainability Index (New Haven: YCELP). 


\section{Figure 1. Distribution of the Indexes}

(a) Genuine Savings

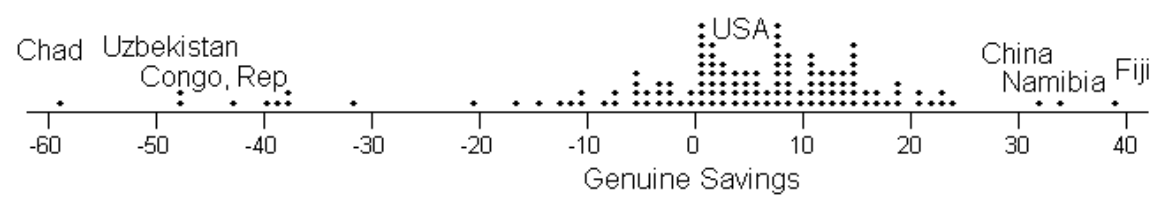

(b) Ecological Footprint Analysis

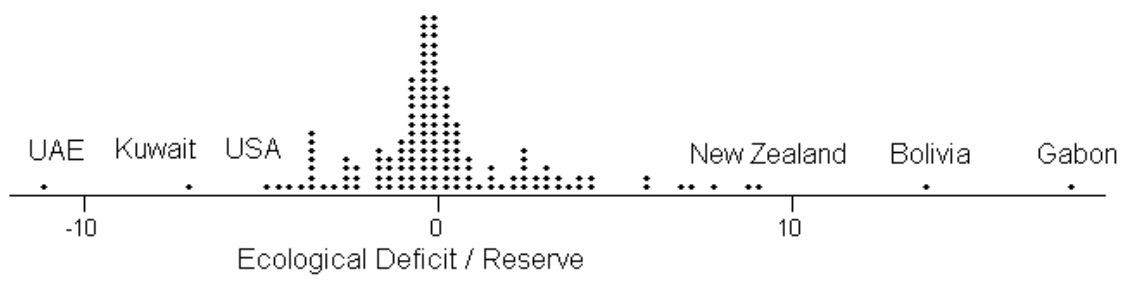

(c) Environmental Sustainability Index

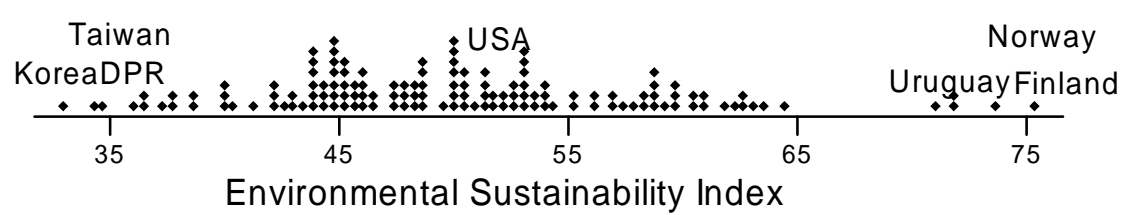

Data sources: Figure 1(a) World Bank (2007); Figure 1(b) WWF et al (2006); Figure 1(c) YCELP et al (2005). 
Figure 2. Distribution of indexes by Income

(a) Genuine Savings by Income

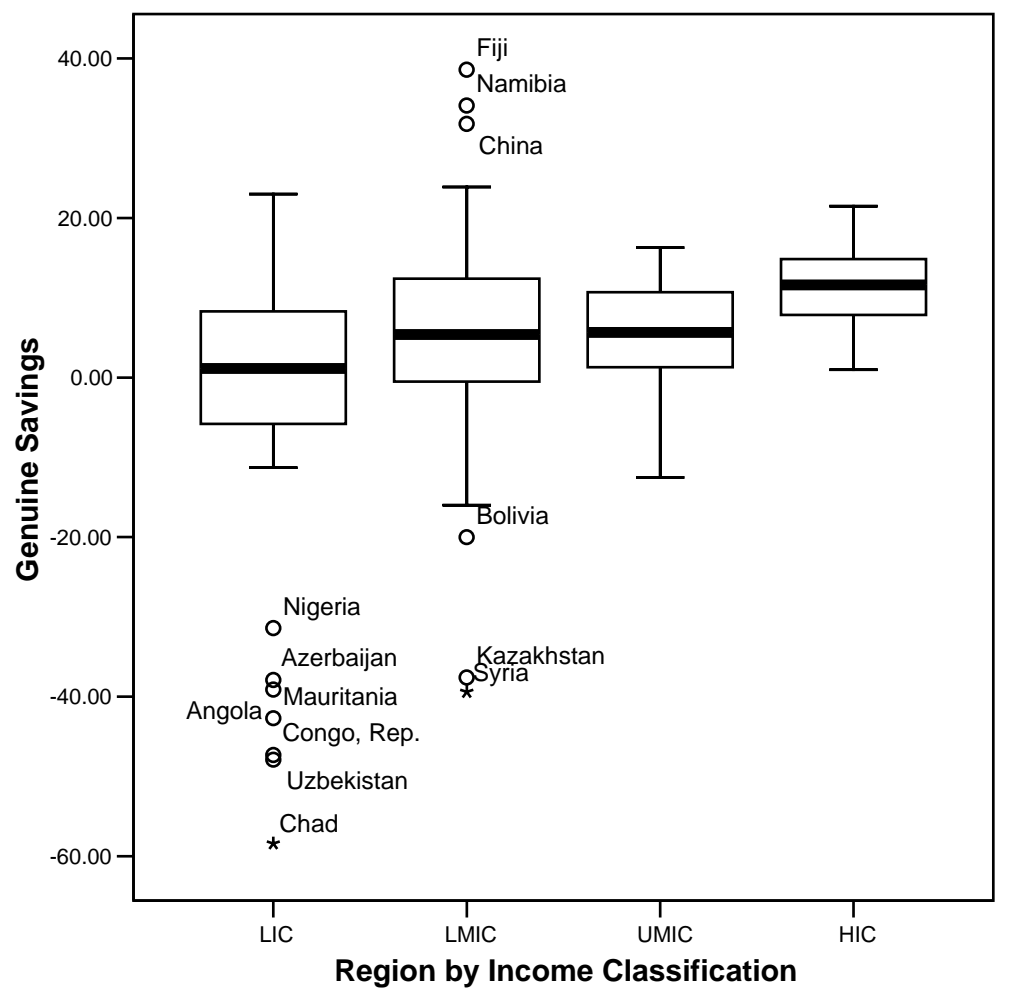

(b) Ecological Deficit/ Reserve by Income

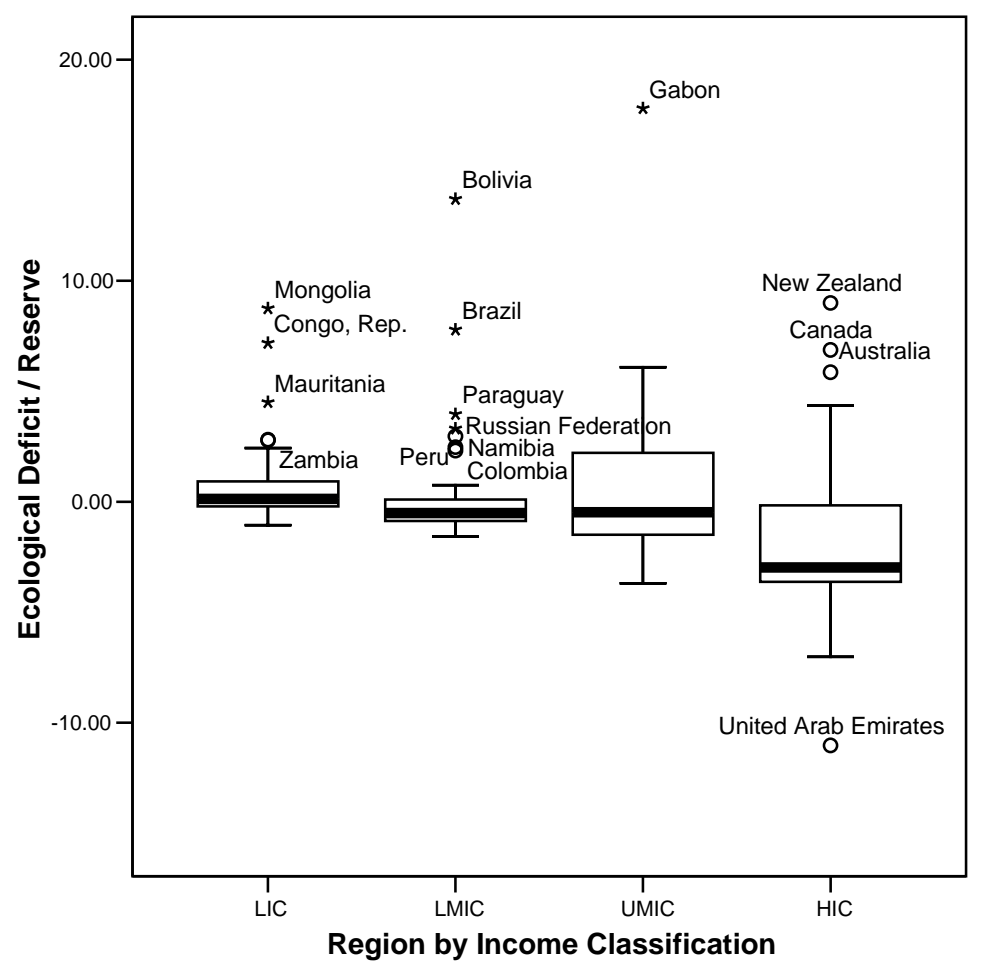


(c) ESI scores by Income

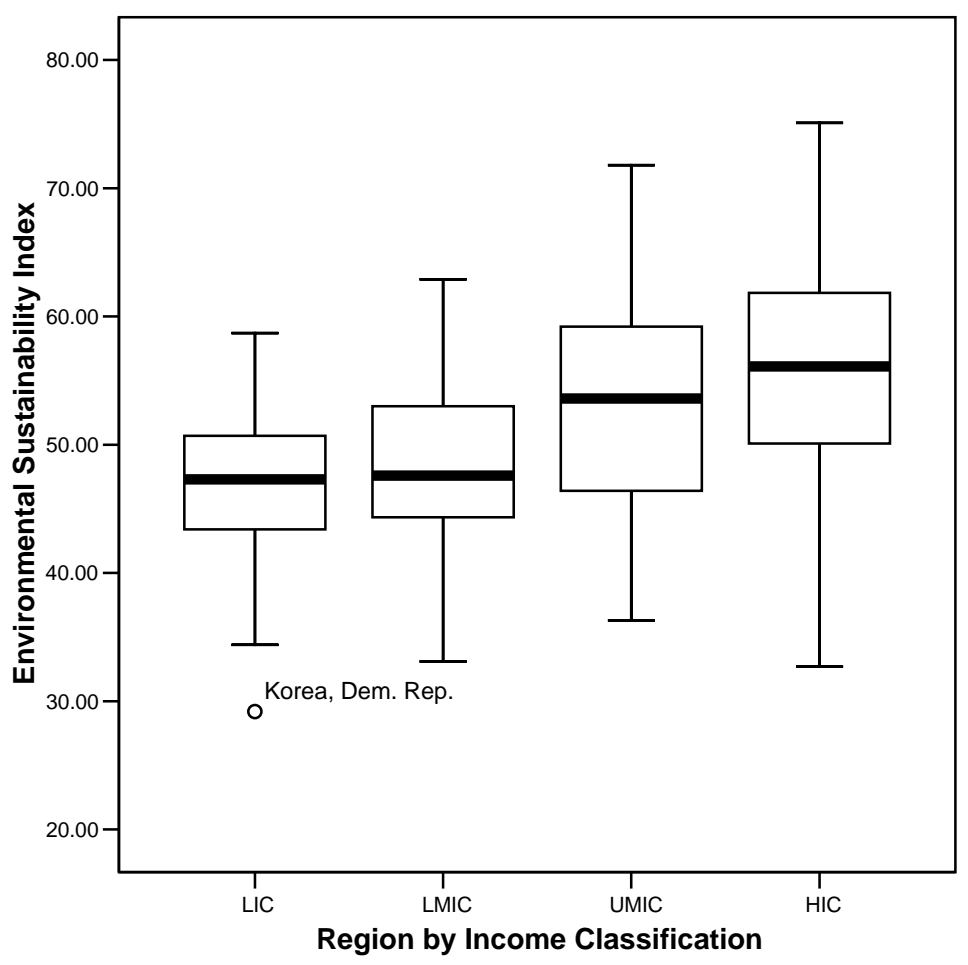


Table 1. Nonparametric Correlations (Kendall tau_b)

\begin{tabular}{|c|c|c|c|c|c|c|}
\hline & & GS & EF & ESI & $\mathrm{Y}$ & HDI \\
\hline \multirow[t]{3}{*}{ GS } & Correlation Coefficient & 1.000 & $-.139^{\star}$ & $.178^{\star *}$ & $.249^{\star \star}$ & $.240^{\star \star}$ \\
\hline & Sig. (2-tailed) & & .023 & .004 & .000 & .000 \\
\hline & $\mathrm{N}$ & 128 & 122 & 121 & 125 & 125 \\
\hline \multirow[t]{3}{*}{ EF } & Correlation Coefficient & $-.139 *$ & 1.000 & $.227 * \star$ & $-.277^{\star \star *}$ & $-.286^{\star \star}$ \\
\hline & Sig. (2-tailed) & .023 & & .000 & .000 & .000 \\
\hline & $\mathrm{N}$ & 122 & 147 & 141 & 135 & 135 \\
\hline \multirow[t]{3}{*}{ ESI } & Correlation Coefficient & $.178^{\star *}$ & $.227^{* \star}$ & 1.000 & $.285^{* \star}$ & $.304^{\star *}$ \\
\hline & Sig. (2-tailed) & .004 & .000 & & .000 & .000 \\
\hline & $\mathrm{N}$ & 121 & 141 & 146 & 136 & 136 \\
\hline \multirow[t]{3}{*}{$\bar{Y}$} & Correlation Coefficient & $.249^{\star \star}$ & $-.277^{\star \star *}$ & $285^{\star \star *}$ & 1.000 & $.800^{\star \star}$ \\
\hline & Sig. (2-tailed) & .000 & .000 & .000 & & .000 \\
\hline & $\mathrm{N}$ & 125 & 135 & 136 & 168 & 168 \\
\hline \multirow[t]{3}{*}{$\mathrm{HDI}$} & Correlation Coefficient & $.240^{* *}$ & $-.286^{\star *}$ & $.304^{* *}$ & $.800 * \star$ & 1.000 \\
\hline & Sig. (2-tailed) & .000 & .000 & .000 & .000 & \\
\hline & $\mathrm{N}$ & 125 & 135 & 136 & 168 & 168 \\
\hline
\end{tabular}

*. Correlation is significant at the 0.05 level (2-tailed).

**. Correlation is significant at the 0.01 level (2-tailed).

Table 2. Number of Countries on Unsustainable Trajectories, Nations Classified by Income

\begin{tabular}{l|lllll}
\hline Index & $\begin{array}{l}\text { Low Income } \\
\text { Countries }\end{array}$ & $\begin{array}{l}\text { Lower Middle } \\
\text { Income } \\
\text { Countries }\end{array}$ & $\begin{array}{l}\text { Upper Middle } \\
\text { Income } \\
\text { Countries }\end{array}$ & $\begin{array}{l}\text { High Income } \\
\text { Countries }\end{array}$ & Total \\
\hline All Indexes & 6 & 4 & 1 & 0 & 11 \\
EF \& ESI & 17 & 15 & 6 & 4 & 42 \\
ESI \& GS & 12 & 4 & 1 & 0 & 17 \\
GS \& EF & 8 & 5 & 1 & 0 & 14 \\
GS only & 21 & 10 & 3 & 0 & 34 \\
EF only & 26 & 29 & 14 & 20 & 89 \\
ESI only & 27 & 16 & 6 & 5 & 54 \\
\hline
\end{tabular}


Table 3. Number of Countries on Unsustainable Trajectories, Nations Classified by HDI

\begin{tabular}{l|llll}
\hline Index & $\begin{array}{l}\text { Low HDI } \\
\text { Countries }\end{array}$ & $\begin{array}{l}\text { Middle HDI } \\
\text { Countries }\end{array}$ & $\begin{array}{l}\text { High HDI } \\
\text { Countries }\end{array}$ & Total \\
\hline All Indexes & 2 & 9 & 0 & 11 \\
EF \& ESI & 8 & 27 & 7 & 42 \\
ESI \& GS & 7 & 10 & 0 & 17 \\
GS \& EF & 3 & 11 & 0 & 14 \\
GS only & 11 & 22 & 1 & 34 \\
EF only & 13 & 44 & 32 & 89 \\
ESI only & 17 & 29 & 8 & 54 \\
\hline
\end{tabular}


Table 4. State of Sustainability in Nations: Top Performers by Indexes

$\begin{array}{llll}\text { All Indexes } & \text { GS Only } & \text { EF Only } & \text { ESI Only } \\ \text { Namibia } & \text { Fiji } & \text { Gabon } & \text { Finland } \\ \text { Sweden } & \text { Namibia } & \text { Bolivia } & \text { Norway } \\ \text { Finland } & \text { China } & \text { New Zealand } & \text { Uruguay } \\ \text { Norway } & \text { Morocco } & \text { Mongolia } & \text { Sweden } \\ \text { New Zealand } & \text { Nepal } & \text { Brazil } & \text { Iceland } \\ \text { Uruguay } & \text { Honduras } & \text { Congo, Rep. } & \text { Canada } \\ \text { Brazil } & \text { Korea, Rep. } & \text { Canada } & \text { Switzerland } \\ \text { Canada } & \text { Ireland } & \text { Uruguay } & \text { Guyana } \\ \text { Mongolia } & \text { Philippines } & \text { Australia } & \text { Argentina } \\ \text { Latvia } & \text { Lesotho } & \text { Mauritania } & \text { Austria } \\ \text { Paraguay } & \text { India } & \text { Finland } & \text { Brazil } \\ \text { Honduras } & \text { Sweden } & \text { Latvia } & \text { Gabon } \\ \text { Australia } & \text { Thailand } & \text { Paraguay } & \text { Australia } \\ \text { Argentina } & \text { Bangladesh } & \text { Argentina } & \text { New Zealand } \\ \text { Central African Rep. } & \text { Mongolia } & \text { Sweden } & \text { Latvia } \\ \text { Peru } & \text { Costa Rica } & \text { Namibia } & \text { Peru } \\ \text { Ghana } & \text { Slovenia } & \text { Chile } & \text { Paraguay } \\ \text { Malaysia } & \text { Armenia } & \text { Peru } & \text { Costa Rica } \\ \text { Georgia } & \text { Austria } & \text { Botswana } & \text { Bolivia } \\ \text { Colombia } & \text { New Zealand } & \text { Zambia } & \text { Croatia } \\ \text { (a) Botom } & \text { Pera } & \end{array}$

$\begin{array}{ll}\text { All Indexes } & \text { GS Only } \\ \text { Algeria } & \text { Guinea } \\ \text { Egypt } & \text { Venezuela } \\ \text { Tajikistan } & \text { Lao PDR } \\ \text { Burundi } & \text { Zimbabwe } \\ \text { Zimbabwe } & \text { Sudan } \\ \text { Lebanon } & \text { Russian Federation } \\ \text { Iran } & \text { Malawi } \\ \text { Nigeria } & \text { Lebanon } \\ \text { Azerbaijan } & \text { Ecuador } \\ \text { Syria } & \text { Iran } \\ \text { Uzbekistan } & \text { Bolivia } \\ & \text { Nigeria } \\ & \text { Kazakhstan } \\ & \text { Azerbaijan } \\ & \text { Angola } \\ & \text { Syria } \\ & \text { Mauritania } \\ & \text { Congo, Rep. } \\ & \text { Uzbekistan } \\ & \text { Chad }\end{array}$

$\begin{array}{ll}\text { EF Only } & \text { ESI Only } \\ \text { Libya } & \text { Vietnam } \\ \text { Portugal } & \text { Zimbabwe } \\ \text { Lebanon } & \text { Lebanon } \\ \text { France } & \text { Burundi } \\ \text { Trinidad and Tobago } & \text { Pakistan } \\ \text { Germany } & \text { Iran } \\ \text { Italy } & \text { China } \\ \text { Korea, Rep. } & \text { Tajikistan } \\ \text { Greece } & \text { Ethiopia } \\ \text { Switzerland } & \text { Saudi Arabia } \\ \text { Netherlands } & \text { Yemen } \\ \text { Japan } & \text { Kuwait } \\ \text { Spain } & \text { Trinidad and Tobago } \\ \text { Saudi Arabia } & \text { Sudan } \\ \text { United Kingdom } & \text { Haiti } \\ \text { Israel } & \text { Uzbekistan } \\ \text { Belgium } & \text { Iraq } \\ \text { United States } & \text { Turkmenistan } \\ \text { Kuwait } & \text { Taiwan } \\ \text { United Arab Emirates } & \text { Korea, Dem. Rep. }\end{array}$

